\title{
THE EFFECT OF DIFFERENT PLASTICIZERS ON THE CHARACTERISTICS OF WHEY COMPOSITE EDIBLE FILM
}

\author{
Fahrullah Fahrullah $^{1,2)}$, Lilik Eka Radiati ${ }^{3)}$, Purwadi Purwadi ${ }^{3)}$, Djalal Rosyidi ${ }^{3 *}$ \\ 1) Doctoral Program, Faculty of Animal Science, Universitas Brawijaya, Jl. Veteran, Malang, 65145, Jawa \\ Timur, Indonesia \\ ${ }^{2)}$ Faculty of Agriculture, Universitas Muhammadiyah Gorontalo, Jl. Prof. Dr. H. Mansoer Pateda, Pentadio \\ Timur, Telaga Biru, 96181, Gorontalo, Indonesia \\ ${ }^{3)}$ Faculty of Animal Science, Universitas Brawijaya, Jl. Veteran, Malang, 65145, Jawa Timur, Indonesia \\ E-mail: djalal_tht@ub.ac.id
}

Submitted 14 January 2020; Accepted 10 February 2020

\begin{abstract}
The edible film is a protective coating that could be directly applied to food products. This research aims to observe the physical characteristics of whey composite edible film with different plasticizer addition (glycerol, sorbitol, polyethylene glycol). The research was conducted as a laboratory experiment and the observed variables were film thickness, tensile strength, elongation at break, water vapor transmission rate (WVTR), and followed with microstructure observation. The research was conducted in a completely randomized design and analyzed with analysis of variance (ANOVA) followed with the least significant difference (LSD) test. The physical measurement of the edible film showed that the thickness was at $0.0286-0.0308 \mathrm{~mm}$, the tensile strength was at 5.72-8.20 N, the elongation at break was around 28.66-57.5\%, and the WVTR was at 7.63-7.96 $\mathrm{g} / \mathrm{m}^{2}$.day. Moreover, the microstructure observation showed that the molecules in the edible film were evenly distributed.
\end{abstract}

Keywords: Edible film; composite; konjac; plasticizer; whey 


\section{INTRODUCTION}

The edible film is a protective coating that could directly be applied to the food products. The coating is aimed to improve the shelf-life and qualities of the food. Aside from providing protection, the film is made from biodegradable materials so it could be safe for the environment as well. The application of film should be able to prevent several factors that could damage the food qualities, such as oxidation, organoleptic changes, microbial growth, and water absorption. Moreover, the widely applied film made from polyethylene and polystyrene is unsafe for the environment while also caused certain substances contamination to the food product. The application of edible film with better protective abilities then offers a better approach to the development of the food coating industry. The application of edible film could improve the food product qualities and prolonging the shelf-life of the product by inhibiting moisture, lipid, aroma and gas transfer. Various polymers such as protein, polysaccharides, and lipids could be used to make the edible film (Wang et al., 2010). One of the promising edible film materials is whey protein, a derivative product from the cheese processing industry. The utilization of whey protein as polymers would produce transparent, soft and flexible film added with aroma barrier properties as well.

Previous research has shown that the edible film could be made from two or more different biopolymers or known as composite edible film. The composite edible film would have better functional properties compared to the edible film made only from one certain polymer (Serna and Pilho, 2015). Previous research focused on the composite edible film have been done, such as with

*Corresponding author:

Djalal Rosyidi

Email: djalal_tht@ub.ac.id

Fakultas Peternakan, Universitas Brawijaya, Jl.

Veteran, Malang, 65145, Jawa Timur, Indonesia konjac glucomannan and whey protein isolate (Janjarasskul et al., 2017), cassava starch and clay nanoparticles (Souza et al., 2015), and pea starch and bean protein isolate (Sun et al., 2013). In this research, the composite materials have shown better homogeneity and better moisture inhibition compared to the single biopolymer edible film, noting that each hydrocolloid materials could specifically complement each other. Another hydrocolloid material which could be used in the edible film is konjac. Konjac contained glucomannan, the main compounds in the Konjac bulbs which mostly used as soluble dietary fiber.

The common problems found in the edible film is its brittleness and firm texture. A plasticizer is a material added in the edible film at a certain concentration (mostly 10 to $60 \%$ of the polymers dry weight) to reduce the protein chain interaction to improve the film flexibility. The correct type and concentration of plasticizer would produce a balanced film mechanical property and permeabilities. The polyol group such as glycerol, sorbitol, and polyethylene glycol (PEG) are commonly used as a plasticizer for the edible film. Those plasticizers are known to be able to initiate various hydrogen bonds and interact with polymers (disrupt the polymer bonds and create spaces between polymer chains) to prevent the water loss.

\section{MATERIALS AND METHODS}

\section{Materials}

The materials used in this research were $8 \%(\mathrm{w} / \mathrm{v})$ whey protein powder, $2 \%$ (w/v) konjac, sorbitol, glycerol, and polyethylene glycol (PEG), aquadest, silica gel, aluminum foil, plastic wrap, paper label, plastic, and tissue. The instruments used were petri dish, micropipette, thermometer,

How to cite:

Fahrullah., Radiati, L.E., Purwadi., \& Rosyidi, D. (2020). The Effect of Different Plasticizers on the Characteristics of Whey Composite Edible Film. Jurnal Ilmu dan Teknologi Hasil Ternak, 15 (1), $31-37$ 
Erlenmeyer flask, magnetic stirrer, hot plate stirrer, micrometer screw, measurement flask, digital gauge HF 500, desiccator, water pass, stopwatch, scissors, digital weight analyzer, tensile strength and elongation at break analyzer, Scanning electron microscope, knife, and clamp.

\section{Methods}

The research was conducted in a completely randomized design with 5 replications. The treatments were different plasticizer addition, which was sorbitol, glycerol, and PEG at 30\% each. All of the data were analyzed with ANOVA and followed with an LSD test to determine significant differences.

\section{Edible film preparation}

Two grams of $8 \%(w / v)$ whey powder was mixed with $0.5 \mathrm{~g}$ of $8 \%(\mathrm{w} / \mathrm{v})$ konjac and diluted with distilled water at $25 \mathrm{~mL}$. The solution was then added with sorbitol, glycerol, or PEG as much as $30 \%$ of the whey and konjac solution according to the treatment.

The solution was then heated at $90^{\circ} \mathrm{C}$ $\pm 2^{\circ} \mathrm{C}$ in the hot plate and simultaneously mixed by using a magnetic stirrer at $250 \mathrm{rpm}$ for $30 \mathrm{~m}$. The film solution was then poured in the petri dish and dried at room temperature for $24 \mathrm{~h}$. The edible film was then packaged by using a paper wrap for $2 \mathrm{~d}$ before analyzed.

\section{Thickness}

The thickness measurement of the edible film was done by using a micrometer screw (0.001 mm accuracy). The thickness was measured by calculating the average thickness from five different areas of the film (4 edges and 1 center).

\section{Elongation at break}

The film was cut at $7 \times 3 \mathrm{~cm}$ with the diameter at $1.5 \mathrm{~cm}$ and hooked on a clamp on both long sides. The formula for elongation at break is as follow:

$$
\% \mathrm{E}=100 \mathrm{X}\left(\mathrm{d}_{\mathrm{after}}-\mathrm{d}_{\mathrm{before}}\right) / \mathrm{d}_{\mathrm{after}}
$$

Description:

E : Elongation

$\mathrm{d}_{\mathrm{after}} \quad$ : Spaces between clamps after pulled until the edible film broke

$\mathrm{d}_{\text {before }}$ : Spaces between clamps before pulled

\section{Tensile strength}

The edible film Ml was cut at $8 \times 3 \mathrm{~cm}$ with the diameter at $1.5 \mathrm{~cm}$ and hooked horizontally on a clamp on both long sides. The maximum tensile strength was measured when the film showed the sign of breakage during the pullout.

\section{Water vapor transmission rate (WVTR)}

The WVTR was measured by firstly cut the edible film into $2.8 \mathrm{~cm}$ diameter. The film was then placed on a glass containing $3 \mathrm{~g}$ of silica gel until it covers the surface. The edible film covered glass was then weighed and placed into a controlled desiccator with humidity at under than $55 \%$. The sample was then weighed every $24 \mathrm{~h}$ for $5 \mathrm{~d}$ to obtain the WVTR value. The obtained WVTR was expressed in $\mathrm{g} / \mathrm{m}^{2}$.day ${ }^{-1}$ and measured by the following formula (Chambi dan Grosso, 2011, with modification):

Description:

$$
\text { WVTR }=[G / t] / A
$$

$\mathrm{G} / \mathrm{t}$ : Added weight over time (g)

A : Surface area of the edible film $\left(\mathrm{mm}^{2}\right)$

\section{Scanning electron microscope}

The microstructure of the edible film was observed by using a scanning electron microscope (SEM) by using SEM JEOL JSM 5310 LV Scanning Microscope. The edible film was cut at $0.5 \times 0.5 \mathrm{~cm}$, and then placed on a carbon covered metal plate and then covered with gold on the magnetron sputtering device equipped with a vacuum. The sample was then scanned and then recorded. 


\section{RESULTS AND DISCUSSIONS}

\section{Whey composite edible film characteristics}

The characteristics of whey composite edible film are presented in Table 1.

\section{Thickness}

In Table 1, it can be seen that the thickness of whey composite edible film in this study did not show a significant difference $(\mathrm{P}>0.05)$ between all treatments. This showed that the different plasticizer at the same concentration $(30 \%)$ resulted in similar edible film thickness. The thickness of the edible film is determined by the total solids content, surface area and volume of the film solution.

The higher total solids content in the film solution is known to produce a thicker film. The thickness of the edible film is important as it would affect the barrier and mechanical properties of the film. Yulianti and Ginting (2012) explained that film thickness would affect water, gas and other volatile compounds transmission.

Table 1. Physical characteristics of the whey composite edible film

\begin{tabular}{lccc}
\hline \multirow{2}{*}{\multicolumn{1}{c}{ Parameters }} & \multicolumn{3}{c}{ Plasticizer $(30 \%)$} \\
\cline { 2 - 4 } & Sorbitol & Glycerol & PEG \\
\hline Thickness $(\mathrm{mm})$ & $0.0308 \pm 0.0029$ & $0.0294 \pm 0.0018$ & $0.0286 \pm 0.0030$ \\
Tensile strength $(\mathrm{N})$ & $7.82^{\mathrm{b}} \pm 0.49$ & $5.72^{\mathrm{a}} \pm 0.43$ & $8.20^{\mathrm{b}} \pm 0.67$ \\
Elongation at break $(\%)$ & $29.86^{\mathrm{a}} \pm 3.34$ & $57.5^{\mathrm{b}} \pm 7.22$ & $28.66^{\mathrm{a}} \pm 4.47$ \\
WVTR $\left(\mathrm{g} / \mathrm{m}^{2}\right.$.day $\left.^{-1}\right)$ & $7.63 \pm 1.08$ & $7.96 \pm 0.89$ & $7.63 \pm 1.23$
\end{tabular}

Description: Different superscripts indicate highly significant differences $(\mathrm{P}<0.01)$

The addition of glycerol as a plasticizer showed the lowest film thickness compared to other plasticizer materials. It is known that glycerol had the lowest molecular weight and total solids content, thus resulted in lower film thickness even though in a similar concentration, the difference was not significant. On the other hand, the thicker edible film would inhibit the gas transmission during respiration, which would accumulate ethanol and caused off-flavors in food, thus a correct film thickness is essential to optimally preserve food quality.

Research by Skurtys et al. (2011) showed that thick edible film would inhibit water vapor and gas transmission, which prolong the shelf-life of the food, but had lower organoleptic properties when consumed.

\section{Tensile strength}

The results of the analysis of variance (Table 1) showed that different plasticizers showed a highly significant difference $(\mathrm{P}<0.01)$ to the tensile strength of whey composite edible film. The addition of glycerol as a plasticizer resulted in a lower film tensile strength compared to sorbitol and PEG. It is caused by the lower molecular weight of glycerol thank sorbitol and PEG. The result is in accordance with Hasnelly et al. (2015) who showed that a positive correlation between the molecular weight of plasticizer to the tensile strength of the produced film. Sorbitol had a molecular weight at 182.17 Da and PEG at 200-600 Da, while glycerol had a lower molecular weight at 92.09 Da (Mudmainnah, 2017). The addition of glycerol would reduce the molecular stress between a matrix in the film, thus produced a weak edible film. The addition of glycerol is also allegedly would reduce the bonding force between starch molecules during evaporation which reduces the film strength towards mechanical treatments.

\section{Elongation at break}

The results showed that different plasticizer addition gave highly significant differences $(\mathrm{P}<0.01)$ to the elongation of 
whey composite edible film. The different elongation was due to the properties of glycerol which increase the intermolecular spaces in the film matrix and reduce the total hydrogen bonds, which would increase the edible film flexibility. Huri and Nisa (2014) explained that the increased addition of glycerol would have resulted in higher film flexibility.

Glycerol could interact with polysaccharides and initiate polysaccharideglycerol bonds which would increase the film elasticity due to the suspension of both molecules. The hydroxyl group on the glycerol chains contributes to the hydrogen initiation between polymer polysaccharides with glycerol during the formation of edible film. Polyol compounds such as glycerol would be effective to reduce the internal hydrogen bonds by creating space between molecules, and reduce the film firmness as well as increasing its flexibility (Oses et al., 2009). The addition of sorbitol as plasticizer produced a good film elongation, but still lower compared to the glycerol addition. Sorbitol is a derivative compound from glycerol with relatively similar characteristics.

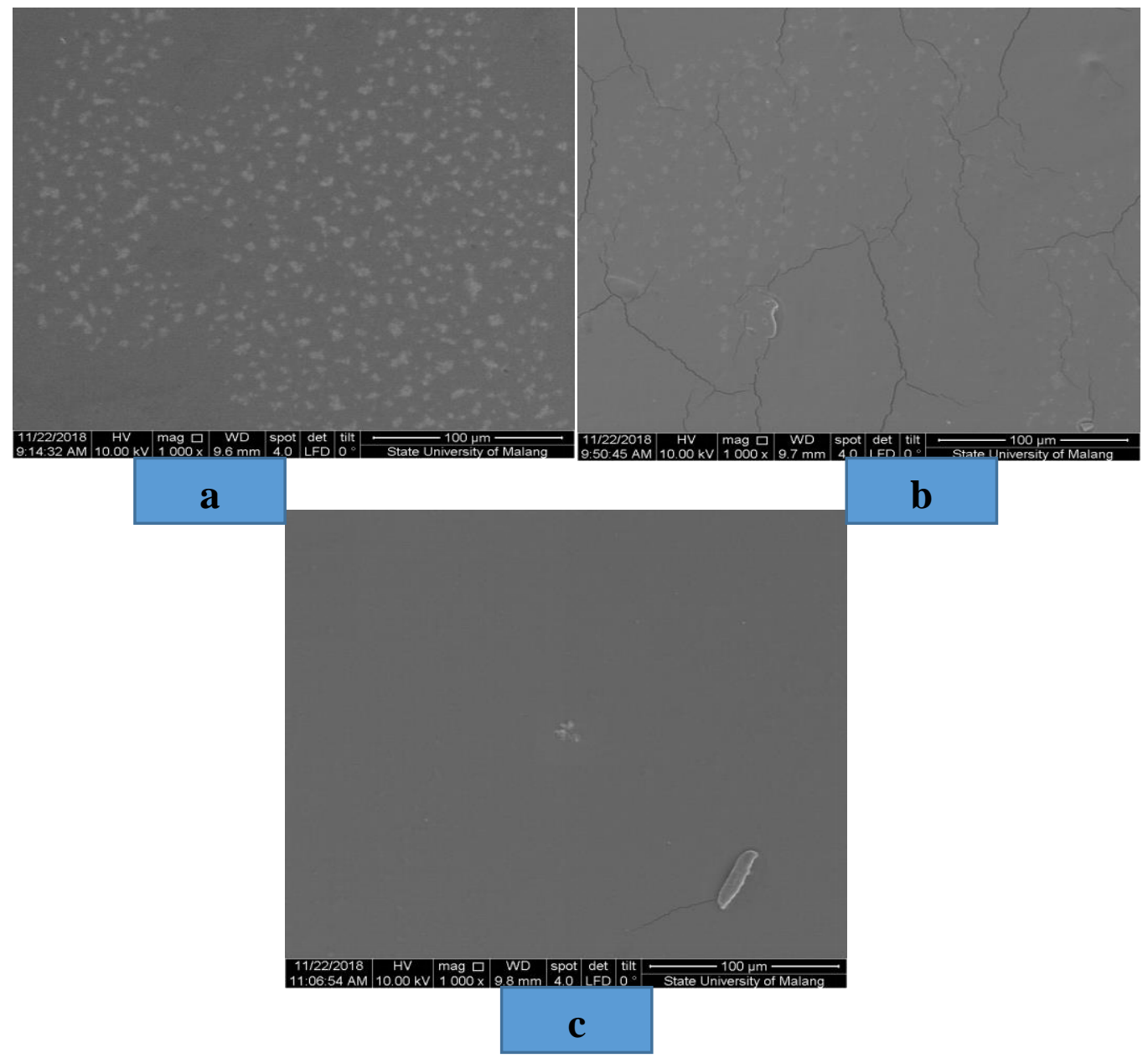

Description: (a) Sorbitol; (b) Glycerol; (c) Polyethylene glycol (PEG)

Figure 1. SEM microstructure observation of whey composite edible film with different plasticizer addition at $1000 \mathrm{x}$ magnification

The edible film plasticizer could be originated from monosaccharides, disaccharides, and oligosaccharides, with all compounds, play a role to reduce the intermolecular forces in the film. The addition of PEG for whey composite edible film in this study showed lower elongation compared to glycerol and sorbitol addition. 
The result was due to the methylcellulose characteristics of PEG that lower the film elongation percentage.

\section{Water Vapor Transmission}

The result showed that the different plasticizer did not show a significant difference $(\mathrm{P}>0.05)$ to the water vapor transmission (WVTR) of the whey composite edible film. However, the highest WVTR was shown on the whey composite edible film added with glycerol. Previous research showed that the plasticizing effect of glycerol on the whey-based edible film could reduce the intermolecular force on the polymer chains, and increase the release of water by free polymers (Janjarasskul, et al., 2011). Moreover, research by Al-Awwaly et al. (2010) showed that higher glycerol addition would increase the WVTR of the edible film due to the increased intermolecular spaces and hydrophilic characteristics of glycerol. The increased intermolecular spaces would provide spaces for water transmission through the protein matrix of the edible film. Plasticizers made from polyol compounds, such as sorbitol, glycerol, and PEG could slip through polymer bounds, break hydrogen bonds, and increase film flexibility as well as the WVTR.

\section{Microstructure}

The microstructure characteristics of the edible film is a determinant factor to the overall film characteristics. The microstructure observation through SEM showed a varying structure, from solid to tenuous and wavy structure. The microstructure of the whey composite edible film in this study is presented in Figure 1.

In Figure 1, it can be seen that sorbitol addition on the whey composite edible film produces an even structure, but the konjac particles were not perfectly bound. The condition indicates a weak bond between molecules. A similar condition can also be seen in glycerol addition, but the addition of glycerol produced cracks in the film. Furthermore, the addition of PEG on whey composite edible film showed a compact and even structure. The microstructure of edible film is known to correlate to its physical characteristics. According to Wang et al. (2010), the less compact structure of edible film indicates weaker film tensile strength. In addition, the polymer molecules' distribution and molecular spaces would also indicate the film elongation at break.

\section{CONCLUSIONS}

The research concludes that the utilization of glycerol as a film plasticizer produced the best physical characteristics (thickness, tensile strength, elongation at break and water vapor transmission rate) of the edible film. The microstructure observation also showed evenly distributed molecules in the film.

\section{ACKNOWLEDGMENT}

The authors would like to thank the BUDI-DN scholarship and Indonesia Endowment Fund for Education of the Indonesian Ministry of Finance as the research sponsors.

\section{REFERENCES}

Al-Awwaly, K. U., \& Wahyuni, A. M. (2010). Pembuatan edible film protein whey: kajian rasio protein dan gliserol terhadap sifat fisik dan kimia. Jurnal Ilmu Dan Teknologi Hasil Ternak, 5(1), 45-56.

Chambi, H. N. M., \& Grosso, C. R. F (2011). Mechanical and water vapor permeability properties of biodegradables film based on methylcellulose, glucomannan, pectin, and gelatin. Ciencia e Tecnologia de Alimentos 31(3): 739-746.

Hasnelly, D., Ina, S.N.D., \& Nasution, M.E.U. (2015). Pemanfaatan whey susu menjadi edible film sebagai kemasan dengan penambahan CMC, 
gelatin dan plasticizer. Pasundan Food Technology Journal, 2(1), 62-69.

Huri, D., \& Nisa, F. C. (2014). The effect of glycerol and apple peel waste extract concentration on the physical and chemical characteristics of edible film. Jurnal Pangan Dan Agroindustri, 2(4), 29-40.

Janjarasskul, T., Tananuwong, K., Leuangsukrerk, M., Phupoksakul, T., \& Borompichaichartkul, C (2017). Effects of hasten drying and storage conditions on properties and microstructure of konjac glucomannan-whey protein isolate blend films. Food Biophysics. 13:49-59 13. https://doi.org 10.1007/s1 1483-017-9510-7.

Mudmainnah, S. (2017). Sintesis SelulosaPolietilen Glikol (PEG) dan Aplikasinya Dalam Sistem Pelepasan Obat Ibuprofen. Bandar Lampung: Fakultas MIPA Universitas Lampung.

Olivas, G. I. I., \& Barbosa-Cánovas, G. (2009). Edible films and coatings for fruits and vegetables. In Edible Films and Coatings for Food Applications (pp. 211-244). https://doi.org/10.1007 /978-0-387-92824-1_7

Osés, J., Fernández-Pan, I., Mendoza, M., \& Maté, J. I. (2009). Stability of the mechanical properties of edible films based on whey protein isolate during storage at different relative humidity. Food Hydrocolloids, 23(1), 125-131. https://doi.org/10.1016/j.foodhyd.200 7.12.003
Serna, P. C., \& Filho, J. F. L. (2015). Biodegradable zein-based blend films:structural, mechanical, and barrier properties. Food Technol. Biotechnol, 53(3), 348-353. http://doi. org/10.17113/ftb.53.03.15.3725.

Skurtys, O., Acevedo, C., Pedreschi, F., Enronoe, J., Osorio, F., \& Aguilera, J. M. (2011). Food hydrocolloid edible films and coatings. In Food Hydrocolloid Edible Films and Coatings. Nova Science Publishers, Inc.

Souza, A. C., Benze, R., Ferrao, E. S., Ditchfield, Coelho, A. C. V., \& Tadini, C. C (2012). Cassava starch biodegradable films influence of glycerol and clay nanoparticles content on tensile and barrier propertiesand glass transition temperature. LWT-Food Sci Technol 46, 110-117. http://dx.doi.org/10.101 6/j.lwt.2011.10.018

Sun, Q., Sun, C., \& Xiong, L (2013). Mechanical, barrier and morphological properties of pea starch and peanut protein isolate blend films. Carbohidrate Polymers, 98. 630-7. http://dx.doi.org/10.1016/j.carbpol.20 13.06.040.

Wang, W. (2016). Introduction to Konjac Andi Johnson Konjac Company Ltd. In 5-403 Long Spring Garden. China: 118 Yang Bridge West Road, Fuzhou city.

Yulianti, R., \& Ginting, E. (2012). Perbedaan karakteristik fisik edible film dari umbi-umbian yang dibuat dengan penambahan plasticizer. Jurnal Penelitian Pertanian Tanaman Pangan, 31(2), 131-136. https://doi. org/10.21082/jpptp.v31n2.2012.p 